Научная статья

УДК 331.5

DOI 10.18101/2304-4446-2021-4-18-23

\title{
СОДЕЙСТВИЕ ТРУДОУСТРОЙСТВУ ВЫПУСКНИКОВ И НЕЗАВИСИМАЯ ОЦЕНКА КАЧЕСТВА ОБРАЗОВАТЕЛЬНОЙ ДЕЯТЕЛЬНОСТИ (НА ПРИМЕРЕ ФГБОУ ВО БГУ)
}

\author{
(C) Барлуков Александр Михайлович \\ кандидат экономических наук, доцент \\ barlukov88@mail.ru
}

\author{
(C) Нимаева Елена Дондоковна \\ ведущий специалист \\ praktika-trud@bsu.ru
}

Бурятский государственный университет имени Доржи Банзарова Россия, 670000, г. Улан-Удэ, ул. Смолина, 24a

\begin{abstract}
Аннотация. Статья посвящена проблемам и перспективам деятельности в рамках поддержки занятости выпускников Бурятского государственного университета имени Доржи Банзарова, в том числе проблемам обеспечения занятости обучающихся в условиях распространения новой коронавирусной инфекции (COVID-19). Также в статье представлены сведения о трудоустройстве выпускников университета с 2016 по 2020 г. и сведения о трудоустройстве выпускников университета с инвалидностью и ОВ3 с 2019 по 2021 г., представлена информация о сотрудничестве университета с общественными организациями в рамках обеспечения занятости обучающихся и выпускников на летний период. Кроме этого, в статье рассмотрены элементы независимой оценки качества образовательной деятельности в условиях внедрения и реализации ФГОС 3++, представлен перечень образовательных программ, реализуемых в университете, по которым получено свидетельство о профессионально-общественной аккредитации.
\end{abstract}

Ключевые слова: мониторинг трудоустройства, рынок труда, кадровый кризис, трудоустройство выпускников, востребованность выпускников.

\section{Для цитирования}

Барлуков А. М., Нимаева Е. Д. Содействие трудоустройству выпускников и независимая оценка качества образовательной деятельности (на примере ФГБОУ ВО БГУ) // Вестник Бурятского государственного университета. Экономика и менеджмент. 2021. № 4. С. 18-23.

Содействие трудоустройству выпускников является одной из ключевых задач деятельности Бурятского государственного университета имени Доржи Банзарова, а также обеспечивает стабильное общественное положение университета на рынке трудовых ресурсов и образовательных услуг региона. В настоящее время в образовательной организации имеются все необходимые условия для продуктивной организации учебного и воспитательного процессов, а также проводятся различные мероприятия по содействию трудоустройству выпускников, включая 
A. М. Барлуков, Е. Д. Нимаева. Содействие трудоустройству выпускников и независимая оценка качества образовательной деятельности (на примере ФГБОУ ВО БГУ)

развитие института наставничества и разработки программы организации стажировок.

Для обеспечения высокого качества подготовки будущих специалистов для экономики региона университет сотрудничает с крупными промышленными, научно-техническими, коммерческими, образовательными и медицинскими организациями республики и соседних регионов, а также с различными органами власти. К примеру, в сфере трудоустройства выпускников заключено более 200 договоров, в сфере практической подготовки обучающихся - более 450 договоров. Планируется дальнейшее расширение связей с данными организациями и предприятиями [1].

В образовательную организацию ежегодно поступают заявки на кадры в количестве более тысячи вакансий. В большинстве случаев данные заявки поступают от средних общеобразовательных учреждений, образовательных организаций СПО и ДПО, лечебно-профилактических учреждений. За последние годы в университете контрольные цифры приема по образовательным программам высшего образования по УГСН 44.00.00 Образование и педагогические науки, 31.00.00 Клиническая медицина, 33.00.00 Фармация существенно увеличились, что, на наш взгляд, поможет решить проблему высокой потребности в кадрах для образовательных и лечебно-профилактических учреждений в рамках нашего региона.

Университет тесно сотрудничает с МOOО «Российские студенческие отряды» и Республиканской школой подготовки вожатых. В летние месяцы 2021 г. в каникулярное время 84 обучающихся университета из студенческого отряда БГУ «АРОН» выехали на путину в Камчатский край, и 55 обучающихся университета успешно окончили Республиканскую школу подготовки вожатых и были трудоустроены в зависимости от эпидемиологической ситуации в регионе в детские оздоровительные лагеря. Также была проведена работа по содействию занятости обучающихся и выпускников университета на летний период 2021 г. в приемной комиссии университета, в которой было трудоустроено 18 обучающихся университета. Университет также планирует с осени 2021 г. участвовать в программе по трудоустройству выпускников 2020 и 2021 гг. на должности научных и инженерно-технических работников.

Кроме этого, с 21 июля 2021 г. университет подключен к цифровой карьерной среде «Факультетус» (резидент СКОЛКОВО). Сегодня проводится работа по привлечению кадровых партнеров университета на данную цифровую платформу.

Необходимо также отметить, что с первых дней борьбы с новой коронавирусной инфекцией по призыву Министерства здравоохранения Республики Бурятия в медицинских организациях г. Улан-Удэ работают ординаторы и студенты старших курсов Медицинского института университета. В конце 2020/21 учебного года в связи с ростом заболеваемости среди населения было трудоустроено в медицинские организации терапевтами 85 клинических ординаторов, помощниками врача - 163 студента 4, 5 курсов Медицинского института за счет практической подготовки с переносом экзаменационной сессии. Они вносят весомый вклад в борьбу с новой коронавирусной инфекцией.

На рис. 1 представлена информация о трудоустройстве выпускников университета с 2016 по 2020 г. В 2020 г. процент трудоустройства выпускников составил 73,2. В предстоящем мониторинге эффективности деятельности образова- 
тельных организаций высшего образования показатель «Трудоустройство выпускников» для выпускников 2021 г. прогнозируется выше порогового значения $-70 \%{ }^{1}$.

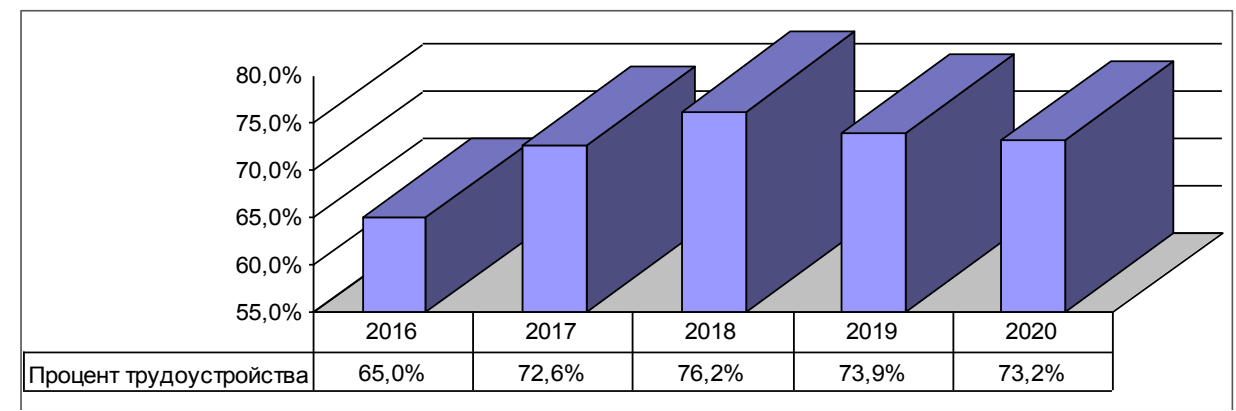

Рис. 1. Трудоустройство выпускников ФГБОУ ВО БГУ с 2016 по 2020 г.

Кроме этого, университет активно сотрудничает с Республиканским агентством занятости населения, в том числе в рамках содействия в трудоустройстве выпускников университета с инвалидностью и ОВЗ на квотируемые рабочие места.

К примеру, в 2019 г. всего выпускников университета с инвалидностью и ОВ3 было 15 человек, из них 2 человека не трудоустроено по состоянию здоровья, 1 человек продолжил обучение, 12 человек трудоустроено.

В 2020 г. количество выпускников с инвалидностью и ОВ3 по университету составило 8 чел., из них 1 человек не трудоустроен по состоянию здоровья, 7 человек трудоустроено.

В 2021 г. окончило университет 12 обучающихся с инвалидностью и ОВ3, из них 2 человека находятся в отпуске по уходу за ребенком, 4 человека продолжили обучение, 6 человек трудоустроено.

В таблице 1 представлена информация о трудоустройстве выпускников университета с инвалидностью и ОВЗ с 2019 по 2021 г.

Таблица 1

Информаџия о трудоустройстве выпускников ФГБОУ ВО БГУ с инвалидностью и ОВЗ с 2019 по 2021 г.

\begin{tabular}{|c|c|c|c|c|c|}
\hline \multirow[t]{2}{*}{$\begin{array}{c}\text { Год } \\
\text { выпуска }\end{array}$} & \multirow[t]{2}{*}{$\begin{array}{c}\text { Количество инвали- } \\
\text { дов, завершивших } \\
\text { обучение по образо- } \\
\text { вательным про- } \\
\text { граммам высшего } \\
\text { образования, чел. }\end{array}$} & \multicolumn{2}{|c|}{$\begin{array}{c}\text { Кол-во трудоустро- } \\
\text { енных инвалидов } \\
\text { молодого возраста } \\
\text { по возрастной струк- } \\
\text { туре, чел. }\end{array}$} & \multirow[t]{2}{*}{$\begin{array}{l}\text { Кол-во инвалидов } \\
\text { молодого возраста, } \\
\text { трудоустроенных по } \\
\text { специальности, чел. }\end{array}$} & \multirow{2}{*}{$\begin{array}{c}\text { Кол-во трудоустро- } \\
\text { енных инвалидов } \\
\text { молодого возраста с } \\
\text { уровнем оплаты } \\
\text { труда ниже средней } \\
\text { заработной платы в } \\
\text { регионе, чел. }\end{array}$} \\
\hline & & $18-24$ & $25-44$ & & \\
\hline 2019 & 15 & 10 & 2 & 12 & 8 \\
\hline 2020 & 8 & 4 & 3 & 5 & 6 \\
\hline 2021 & 12 & 4 & 2 & 6 & 4 \\
\hline
\end{tabular}

\footnotetext{
${ }^{1}$ Практика и содействие трудоустройству. URL: http://www.bsu.ru/university/employment/ (дата обращения: 01.10.2021). Текст: электронный.
} 
A. М. Барлуков, Е. Д. Нимаева. Содействие трудоустройству выпускников и независимая оценка качества образовательной деятельности (на примере ФГБОУ ВО БГУ)

В условиях внедрения и реализации ФГОС 3++ независимая оценка качества образовательной деятельности становится одним из ключевых показателей качества подготовки обучающихся и уровня формирования компетенций выпускника, что в последующем повлияет на уровень занятости молодых специалистов университета.

В настоящее время в университете элементами независимой оценки качества образовательной деятельности являются интернет-тренажеры в сфере образования для ВО и СПО, федеральный интернет-экзамен в сфере профессионального образования (ФЭПО и ФЭПО-ПРО) для ВО и СПО, федеральный интернетэкзамен для выпускников бакалавриата, диагностическое интернет-тестирование обучающихся 1-го курса для ВО и СПО, профессионально-общественная аккредитация образовательных программ (табл. 2).

Таблица 2

Информация о профессионально-общественной аккредитациии образовательных программ ФГБОУ ВО БГУ

\begin{tabular}{|c|c|c|c|}
\hline $\begin{array}{c}\text { Код специаль- } \\
\text { ности, } \\
\text { направления } \\
\text { подготовки }\end{array}$ & $\begin{array}{c}\text { Наименование } \\
\text { специальности, } \\
\text { направления } \\
\text { подготовки, } \\
\text { образовательной } \\
\text { программы }\end{array}$ & $\begin{array}{c}\text { Наименование } \\
\text { аккредитующей } \\
\text { организации }\end{array}$ & $\begin{array}{c}\text { Срок действия } \\
\text { профессионально- } \\
\text { общественной } \\
\text { аккредитации } \\
\text { (дата окончания } \\
\text { действия свидетель- } \\
\text { ства о профессиональ- } \\
\text { но-общественной } \\
\text { аккредитации) }\end{array}$ \\
\hline \multirow{2}{*}{40.03 .01} & $\begin{array}{c}\text { юриспруденция, ба- } \\
\text { калавриат, образова- } \\
\text { тельная программа } \\
\text { «Международное } \\
\text { право» }\end{array}$ & $\begin{array}{c}\text { общероссийская об- } \\
\text { щественная органи- } \\
\text { зация «Ассоциация } \\
\text { юристов России» } \\
\text { (г. Москва) }\end{array}$ & 5 лет (по 02.12.2024) \\
\hline & $\begin{array}{c}\text { юриспруденция, ба- } \\
\text { калавриат, } \\
\text { образовательная } \\
\text { программа «юрис- } \\
\text { пруденция» }\end{array}$ & $\begin{array}{c}\text { общероссийская об- } \\
\text { щественная органи- } \\
\text { зация «Ассоциация } \\
\text { юристов России» } \\
\text { (г. Москва) }\end{array}$ & 5 лет (по 02.12.2024) \\
\hline 40.04.01 & $\begin{array}{c}\text { юриспруденция, ма- } \\
\text { гистратура, } \\
\text { профиль образова- } \\
\text { тельная программа } \\
\text { «Юриспруденция» }\end{array}$ & $\begin{array}{c}\text { общероссийская об- } \\
\text { щественная органи- } \\
\text { зация «Ассоциация } \\
\text { юристов России» } \\
\text { (г. Москва) }\end{array}$ & 5 лет (по 02.12.2024) \\
\hline 38.03 .01 & $\begin{array}{c}\text { экономика, бака- } \\
\text { лавриат, } \\
\text { образовательная } \\
\text { программа «Бухгал- } \\
\text { терский учет, анализ } \\
\text { и аудит }\end{array}$ & $\begin{array}{c}\text { Союз «Волгоградская } \\
\text { торгово- } \\
\text { промышленная } \\
\text { палата» } \\
\text { (г. Волгоград) }\end{array}$ & 5 лет (по 21.03.2023) \\
\hline
\end{tabular}


Таким образом, деятельность по содействию трудоустройству выпускников является одной из приоритетных задач образовательной организации высшего образования, где востребованность выпускников университета на рынке труда является показателем данной деятельности. Как ранее было отмечено, в ФГБОУ ВО БГУ доля трудоустроенных выпускников 2020 г. составляет 73,2\%, при этом достаточно большое количество выпускников университета продолжает обучение в магистратуре, ординатуре, аспирантуре, что в будущем даст им дополнительные преимущества в последующем трудоустройстве.

\section{Литература}

1. Барлуков А. М. О роли вуза в становлении карьеры молодого специалиста (на примере Бурятского государственного университета имени Доржи Банзарова) // Проблемы и перспективы развития воспитательной работы в вузе: материалы I Межвузовской научно-практической конференции (г. Томск, 14 ноября 2019 г.). Томск: Изд-во Томского гос. ун-та систем управления и радиоэлектроники, 2019. С. 55-58. Текст: непосредственный.

2. Практика и содействие трудоустройству. URL: http://www.bsu.ru/university/ employment/ (дата обращения: 01.10.2021). Текст: электронный.

Статья поступила в редакцию 19.10.2021; одобрена после рецензирования 29.10.2021; принята к публикации 01.11.2021.

\section{ON PROMOTION OF THE EMPLOYMENT OF GRADUATES AND INDEPENDENT ASSESSMENT OF THE QUALITY OF EDUCATIONAL ACTIVITIES (the case of Buryat State University)}

Aleksandr M. Barlukov

Cand. Sci. (Econ.), A/Prof.

barlukov88@mail.ru

Elena D. Nimaeva

Leading Specialist of Department for Planning and Organization

of Educational Process,

Learning and Teaching Office

praktika-trud@bsu.ru

Dorzhi Banzarov Buryat State University

24a Smolina St., Ulan-Ude 670000, Russia

Abstract. The article is devoted to the problems and prospects of promotion the employment of graduates from Dorzhi Banzarov Buryat State University, as well as to the issues of employment in the context of the spread of a new coronavirus infection (COVID-19). The article also presents data on the employment of university graduates in 2016-2020, and graduates with disabilities in 2019-2021, provides information on the cooperation of the university with public organizations in terms of ensuring the employment of students and graduates for the summer period. In addition, the article considers the elements of the independent assessment of the quality of educational activities in the context Federal State Education Standards $3++$, presents a list of educational programs with a certificate of professional and public accreditation implemented at the university. 
А. М. Барлуков, Е. Д. Нимаева. Содействие трудоустройству выпускников и независимая оценка качества образовательной деятельности (на примере ФГБОУ ВО БГУ)

Keywords: monitoring of employment, labour market, personnel crisis, employment of graduates, demand for graduates.

\section{For citation}

Barlukov A. M., Nimaeva E. D. On Promotion of the Employment of Graduates and Independent Assessment of the Quality of Educational Activities (the case of Buryat State University). Bulletin of Buryat State University. Economy and Management. 2021; 4: 18-23 (In Russ.).

The article was submitted 19.10.2021; approved after reviewing 29.10.2021; accepted for publication 01.11.2021. 